\title{
Substitution of Chemical Fertilizer Using Natural Hormone and Cow Biourine On Growth and Yield of Shallot (Allium Cepa $\mathbf{L}$.)
}

\author{
Lagiman, Ihvan Mei Nugraha, Ami Suryawati*, Supono Budi Sutoto \\ Agrotechnology Study Program, Faculty of Agriculture UPN "Veteran" Yogyakarta, \\ Jl. SWK 104 Yogyakarta 55282, Indonesia.Tel.+62-274-486733, Fax: +62-486400 \\ Email*: ami_suryawati@yahoo.com
}

\begin{abstract}
The use of natural hormone of sprout extract, coconut water, and banana stem extract and application of cow biourine has been introduced as an innovation to reduce the use of chemical fertilizers to increase the productivity of shallot. This study aims to compare the growth and yield of shallot with chemical fertilizer treatment and that of shallot treated with combination of natural hormone and cow biourine. The study was conducted in Temon Wetan, Temon, Kulon Progo, Special Region of Yogyakarta using a Complete Randomized Block Design, which consists of two factors and one control (chemical fertilizer). The first factor is a natural hormone: sprout extract, banana stem extract and coconut water. The second factor is the concentration of cow biourine: $30 \%, 40 \%$, and $50 \%$. Data were analyzed using diversity at 5\% level, Orthogonal Contras at 5\% level and DMRT Test with 5\% level. It was revealed that the control group with a combined treatments was not significantly different from the growth and yield of shallot of the group with chemical fertilizers. Types of treatments with natural hormone and cow biourine concentrations provided the same growth and yield as that of chemical fertilizer.
\end{abstract}

Keywords: Cow Biourine, Natural hormone, Shallot

\section{INTRODUCTION}

Shallots are one of the main vegetable commodities in Indonesia that provide many benefits. Onion is included in the spice group which is not classified into the basic needs, but its function as a food seasoning is almost irreplaceable (Waluyo and Sinaga, 2015). The production of shallot in the Special Region of Yogyakarta in 2014-2015 according to the Central Statistics Agency and the Directorate General of Horticulture in the 2017 Agricultural Statistics book was 12,360 tons, while in 2015 it was 8,799 tons. The consumption of red onions in 2014 was 2.49 $\mathrm{kg} / \mathrm{capita} /$ year while in 2015 it was $2.71 \mathrm{~kg} / \mathrm{capita} /$ year. This shows the decreasing production of red onions despite the increasing level of consumption of red onions leading to a shortage of onion production to meet the market demands. To overcome the dwindling production of red onions in the Special Region of Yogyakarta, farmers are recommended to use balanced fertilizer between inorganic and organic fertilizers. Inorganic fertilizers is chemical, physical and or biological engineering fertilizers manufactured by the industry or factories. The advantage of inorganic fertilizers lies in its nutrient content covering all elements to be adjusted to the needs of plants. This type of fertilizer dissolves easily enabling plant to quick absorption and is practical in use.

However, it comes up with a disadvantage of being easily washed out, lowering the $\mathrm{pH}$ of the soil, polluting the water and causing several problems in the soil due to continuous use. The shortcomings of chemical fertilizers can be suppressed by the provision of natural hormones and organic fertilizer. Hormones are non-nutrient organic compounds that can support plant physiological processes. Plants in favorable conditions can easily obtain the required nutrients in sufficient quantities, but plants still need a mechanism for regulating growth called hormones in small amounts (Weaver, 1972). The natural hormones used in this study came from sprouts extract, coconut water, and banana stem extract. This natural hormone has a hormone content of a type of auxin that can support cell elongation and gibberellins. This content can support root growth in high concentrations to help in stimulating root and leaf growth (Marfiani et al. 2014). Meanwhile, cytokines in coconut water have an important role in the process of cell division to help form buds and lengthen the stem. Natural hormones are used because they are derived from organic materials which are more environmentally friendly, easily available, safe to use, and cheaper.

This study used liquid organic fertilizer derived from cow biourine. According to Elisabeth (2013), cow urine liquid fertilizer contains rich nutritional content, such as Nitrogen. Nitrogen is beneficial for the vegetative phase of plant growth. Liquid organic fertilizer from cows contains nutrients $\mathrm{N}, \mathrm{P}, \mathrm{K}$, and $\mathrm{Ca}$ which are bound in organic compounds such as urea, ammonia, creatinine, and keratin. Bovine biourine was used because it has an advantage over cow urine because fermented cow urine (biourine) contains $2.7 \% \mathrm{~N}, 2.4 \% \mathrm{P} 3.8 \%$, Ca $5.8 \%$ of black color and reduced odor than non-fermented cow urine. According to Kurniadinata (2007) the use of cow biourine as organic fertilizer has many advantages since 
it is relatively cheaper, easy to obtain and apply and contains higher $\mathrm{N}$ and $\mathrm{K}$ elements than solid cow manure. Thus, the use of natural hormones and cow biourine can help increase the growth and yield of onion plants. On this basis, it is necessary to conduct a research on "Substitution of Chemical Fertilizers with the Use of Natural Hormones and Cow Biourine on Growth and Yield of Shallot Plants."The purpose of this study is to compare the growth and yield of shallot plants with the treatment of chemical fertilizers and natural hormones plus cow biourine".

\section{MATERIALS AND METHODS}

The research was conducted in Temon Wetan Village, Temon District, Kulon Progo Regency, Special Region of Yogyakarta at a height of 100 meters above sea level with Alluvial soil types. The materials used in this study were the tubers of Sri Kayang variety, natural growth regulator derived from sprout extract, coconut water, and banana stem extract, dolomite, $\mathrm{KCl}$ fertilizer $\left(150 \mathrm{~kg}^{-}\right.$ $\left.{ }^{1}\right)$, SP-36 (150 kg ha-1), Urea (250 kg ha-1), ZA (180 kg $\left.\mathrm{ha}^{-1}\right)$, pesticides, sugar cane drops, EM4, empon, Dithane M-45 80WP fungicide, and cow urine. The tools used in this study include tractors, hoes, sickles, nameplates, analytical scales, water pumps, water hoses, torches, buckets, ruler, bamboo, sprayer tanks, digital cameras, calipers, mulch, mulch clips and writing instrument.

The field experiment was conducted using Complete Randomized Block Design (RCBD) which consists of two factors. Factor I was a natural growth regulator, consisting of 3 levels: sprout extract, banana stem extract, coconut water, while Factor II was the concentration of beef biourine consisting of 3 levels: $40 \%, 50 \%$ and $60 \%$. These two factors led to 9 treatment combinations and 1 control (chemical fertilizer), which was repeated 3 times. The parameters observed were plant height and number of leaves per clump at 14, 28, 42 and 56 days and number of tubers per clump and weight of dried tubers per sample plot. The data obtained were analyzed using diversity analysis (ANOVA) at 5\% level. To find out the difference between the control and the treatment, the researchers performed Orthogonal Contras test at a level of $5 \%$, and in case of a real difference between the treatments, a Duncan's Multiple Range Test (DMRT) was carried out at the level of $5 \%$.

\section{RESULTS AND DISCUSSION}

\section{Plant Height: 14.28.42 and 56 days}

The analysis of observational data onion plants in Table 1 shows that the height of plants in the control group applying Urea and ZA supplementary fertilizers was significantly higher than the 14-day treatment of combination. This is presumably because the control group of onion plants get more sufficient nitrogen for vegetative growth compared to combined treatments with supplementary fertilizer using cow biourine at the age of 7 days. Nutrient Nitrogen derived from Urea and ZA fertilizer has been available so that plants can directly absorb nutrients for plant growth. Cow biourin does not provide optimal results because the nutrients contained in cow biourin are not sufficient to meet the vegetative growth needs of plants. Vegetative growth compared to combined treatments with supplementary fertilizer using cow biourine at the age of 7 days. Nutrient Nitrogen derived from Urea and ZA fertilizer has been available so that plants can directly absorb nutrients for plant growth. Bovine biourine does not provide optimal results because the nutrients of bovine biourine cannot suffice the vegetative growth needs of plants. According to Arumingtiyas (2014), biourine contains Nitrogen in a form that is not readily available to plants. Hence, it requires a mineralisation process to be absorbed by plants.

Table 1. Average Plant Height Age at 14.28.42 and 56 Days (cm).

\begin{tabular}{lllll}
\hline \hline \multicolumn{1}{c}{$\begin{array}{c}\text { Type of } \\
\text { Growth } \\
\begin{array}{c}\text { Regulatory } \\
\text { Substances }\end{array}\end{array}$} & $\mathbf{1 4}$ & $\mathbf{4}$ & $\mathbf{4 2}$ & $\mathbf{5 6}$ \\
\cline { 2 - 5 } Age (days) \\
\hline $\begin{array}{l}\text { Sprout Extract } \\
\text { Banana Stem }\end{array}$ & $24,51 \mathrm{p}$ & $29,83 \mathrm{p}$ & $33,01 \mathrm{p}$ & $35,52 \mathrm{p}$ \\
Extract & $29,68 \mathrm{p}$ & $33,08 \mathrm{p}$ & $35,19 \mathrm{p}$ \\
Coconut Water & $25,08 \mathrm{p}$ & $29,74 \mathrm{p}$ & $33,02 \mathrm{p}$ & $35,97 \mathrm{p}$ \\
\hline Cow Biourine & & & & \\
Concentration & & & & \\
\hline $30 \%$ & $25,57 \mathrm{a}$ & $29,36 \mathrm{a}$ & $33,09 \mathrm{a}$ & $36,16 \mathrm{a}$ \\
$40 \%$ & $23,71 \mathrm{~b}$ & $29,69 \mathrm{a}$ & $32,95 \mathrm{a}$ & $35,49 \mathrm{a}$ \\
$50 \%$ & $25,37 \mathrm{a}$ & $30,21 \mathrm{a}$ & $33,07 \mathrm{a}$ & $35,03 \mathrm{a}$ \\
\hline The Combined & $24,88 \mathrm{x}$ & $29,75 \mathrm{x}$ & $33,04 \mathrm{x}$ & $35,56 \mathrm{x}$ \\
Treatment & $(-)$ & $(-)$ & $(-)$ & $(-)$ \\
\hline Control & $27,43 \mathrm{y}$ & $32,48 \mathrm{x}$ & $35,13 \mathrm{x}$ & $36,93 \mathrm{x}$ \\
\hline \hline
\end{tabular}

Note: The treatment mean followed by the same letter in the same column shows that there is no significant difference in the Duncan's Multiple Range Test (DMRT) with a real level of $5 \%$. The sign ( $\mathrm{x})$ shows no significant difference between the control and the treatment in the Orthogonal Contras test. The (-) sign indicates there is no interaction.

The treatment of natural growth regulators of sprouts extract, banana stem extract, and coconut water showed no significant different height of shallot plants aged 14, 28,42 , and 56 days. This is presumably because the natural growth regulators contain the same hormones namely auxin, cytokinin, and gibberellins. In addition, the effectiveness of growth regulators is also influenced by the environmental factors since at the beginning of the study, rain was so frequent that might impede the response of natural growth regulators to plant metabolism. This is in line with Leopold (1963) explaining that the effect of the application of growth regulators varies for each type of plant, even different between varieties within a species. In addition, the 
effectiveness of using growth regulators is greatly influenced by environmental factors including the factors of the plant itself. Biourine is a liquid organic fertilizer derived from the fermentation process. The fermentation process aims to increase the availability of nutrients available to plants and adding it with microorganisms. This study used liquid organic fertilizer derived from cow urine because it contains higher level of nitrogen content than that of the solid fertilizer of Sutari (2010).

There was a significant different effect of the application of cow biourine concentration in the plant height of 14 days in that the application of $30 \%$ cow biourine concentration was better than the the application of $40 \%$ of cow biourine concentration. Cow biourine concentration $30 \%$ is the best concentration for the absorption of plant nutrients for vegetative growth and to enable optimal growth of the plant. In contrast, the concentration of bovine biourine $40 \%$ of onion plants did not give optimal results. According to Rizki et al. (2014), the application of large amounts of cow biourine would hamper plants in their growth, flowering and fruiting. Contrastively, the administration of cow biourine concentrations that is too little will not significantly affect the plants.

\section{Number of Leaves per Clump of Age 14,28,42 and 56 days}

Table 2. Average Number of Leaves per Clump of Age 14,28,42 and 56 Days (Sheet).

\begin{tabular}{|c|c|c|c|c|}
\hline \multirow{2}{*}{$\begin{array}{l}\text { Type of Growth } \\
\text { Regulatory } \\
\text { Substances }\end{array}$} & \multicolumn{4}{|c|}{ Age (days) } \\
\hline & 14 & 28 & 42 & 56 \\
\hline Sprout Extract & $19,51 \mathrm{p}$ & $28,15 \mathrm{q}$ & $30,64 \mathrm{p}$ & $30,31 \mathrm{p}$ \\
\hline $\begin{array}{l}\text { Banana Stem } \\
\text { Extract }\end{array}$ & $21,89 \mathrm{p}$ & $34,06 \mathrm{p}$ & $33,47 \mathrm{p}$ & $31,71 \mathrm{p}$ \\
\hline Coconut Water & $21,47 p$ & $33,53 \mathrm{pq}$ & $33,01 \mathrm{p}$ & $31,75 \mathrm{p}$ \\
\hline $\begin{array}{l}\text { Cow Biourine } \\
\text { Concentration }\end{array}$ & & & & \\
\hline $30 \%$ & $21,62 \mathrm{a}$ & $32,71 \mathrm{a}$ & $33,12 \mathrm{a}$ & $31,89 \mathrm{a}$ \\
\hline $40 \%$ & $19,53 \mathrm{a}$ & $30,60 \mathrm{a}$ & $31,20 \mathrm{a}$ & $30,31 \mathrm{a}$ \\
\hline $50 \%$ & $21,71 \mathrm{a}$ & $32,44 \mathrm{a}$ & 32,80 a & $31,57 \mathrm{a}$ \\
\hline $\begin{array}{l}\text { The Combined } \\
\text { Treatment }\end{array}$ & $20,96 \times(-)$ & $31,92 \times(-)$ & $32,37 \times(-)$ & $31,26 \times(-)$ \\
\hline Control & $21,87 \mathrm{x}$ & $35,73 \mathrm{x}$ & $35,10 \mathrm{x}$ & $34,93 x$ \\
\hline
\end{tabular}

Note: The treatment mean followed by the same letter in the same column shows that there is no significant difference in the Duncan's Multiple Range Test (DMRT) with a real level of $5 \%$. The sign (x) shows no significant difference between the control and the treatment in the Orthogonal Contras test. The (-) sign indicates there is no interaction.

The number of leaves per clump in Table 2 shows no significant difference between controls and combined treatment group. The type of treatment of natural growth regulators of sprouts extract, banana stem extract, and coconut water showed no significant difference in ages $14,28,42$, and 56 days. Likewise, the administration of bovine biourine concentrations of $30 \%, 40 \%$, and $50 \%$ were not significantly different at $14,28,42$, and 56 days. This is because the leave production of onion plant per clump is influenced by genetic factors as indicated by the number of leaves per clump produced equally. This is in line with the fact that one clump of Srikayang red onions can produce 6 leaves.

Type of treatment of natural growth regulators from sprout extract, banana stem extract, and coconut water showed no significant difference at 14, 42, and 56 days but significantly different at 28 days. The results showed that natural growth regulators from banana stem extract were better than natural growth regulators from coconut water and sprout extracts on the number of leaves per clump parameter. This is because the hormone content in banana stem known as gibberellins and cytokinins can stimulate lateral bud cell division, bud eye growth, which activate dormant buds enabling faster growth of tip of leaves. Subhan (2004) showed that banana stem contains $\mathrm{Mg}$ content of $800 \mathrm{ppm}$ which plays a role in the formation of leaves, increase the results of photosynthesis, and produce greener leaf color.

\section{Number of Tuber per Clump}

Table 3. Average Number of Tubers Per Clump (tubers).

\begin{tabular}{lllll}
\hline \hline \multicolumn{1}{c}{$\begin{array}{c}\text { Type of } \\
\text { Growth } \\
\begin{array}{c}\text { Regulatory } \\
\text { Substances }\end{array}\end{array}$} & \multicolumn{3}{c}{$\begin{array}{c}\text { Cow Biourine } \\
\text { Concentration }\end{array}$} & Average \\
\cline { 2 - 4 } & $\mathbf{3 0 \%}$ & $\mathbf{4 0 \%}$ & $\mathbf{5 0 \%}$ & \\
\hline $\begin{array}{l}\text { Sprout Extract } \\
\text { Banana Stem }\end{array}$ & 12,00 & 11,00 & 10,67 & $11,22 \mathrm{p}$ \\
Extract & 12,00 & 11,00 & 12,67 & $11,89 \mathrm{p}$ \\
Coconut Water & 12,33 & 10,33 & 13,00 & $11,89 \mathrm{p}$ \\
\hline Average & $12,11 \mathrm{a}$ & $10,78 \mathrm{a}$ & $12,11 \mathrm{a}$ & $11,67 \mathrm{x}(-)$ \\
\hline Control & & & & $11,00 \mathrm{x}$ \\
\hline \hline
\end{tabular}

Note: The average treatment followed by the same letter in the same row or column shows no significant difference in the Duncan's Multiple Range Test (DMRT) with a 5\% real level. The sign (x) shows no significant difference between the control and the treatment in the Orthogonal Contras test. The (-) sign indicates there is no interaction.

Variance analysis results on the number of tubers per clump showed that the control treatment with a combination of treatments had no significant effect on the growth of onion. Likewise, treatment of natural growth regulators and administration of bovine biourine concentration had no significant effect on the number of tubers per clump. There were no interactions between the two treatments. The average number of tubers per family of 60 days is presented in Table 3 . The number of tubers per clump of control treatment group and the combined treatment of natural growth regulators plus cow biourine was not significantly different. The control group applicating Urea and $\mathrm{Za}$ fertilizers can be replaced with administration of cow biourine because cow biourine also contains Nitrogen, Phosphorus, Potassium, and Calcium nutrients that plants need. Nitrogen and 
Phosphorus nutrients in bovine biourine develop faster plant growth so that the number of tubers produced is not different from the control group. The application of cow biourine concentrations of $30 \%, 40 \%$, and $50 \%$ did not show any significant difference in the number of tubers per clump. This shows optimal and equal nutrient absorption in the range of the three concentrations of the biourine, leading to optimal number of tubers per clump that is not significantly different.

Treatment of natural growth regulators from sprout extract, banana stem extract, and coconut water did not show any significant difference to the number of tubers per clump and that of other parameters. This is presumably because natural growth regulators were only given 1 time before the tubers were planted. As a result, it only affected the initial growth, such as the germination phase of the tuber. Afterwords, the growth is merely influenced by environmental factors.

\section{Weight of Dry Tubers Per Sample Plot (kg)}

Table 4. Average Dry Tubers Per Sample Plot (kg).

\begin{tabular}{llcll}
\hline \multicolumn{1}{c}{$\begin{array}{c}\text { Type of } \\
\text { Growth } \\
\begin{array}{c}\text { Regulatory } \\
\text { Substances }\end{array}\end{array}$} & \multicolumn{3}{c}{$\begin{array}{c}\text { Cow Biourine } \\
\text { Concentration }\end{array}$} & Average \\
\cline { 2 - 4 } & $\mathbf{3 0 \%}$ & $\mathbf{4 0 \%}$ & $\mathbf{5 0 \%}$ & \\
\hline $\begin{array}{l}\text { Sprout Extract } \\
\text { Banana Stem }\end{array}$ & 1,61 & 1,59 & 1,71 & $1,64 \mathrm{p}$ \\
Extract & 1,87 & 1,77 & 1,55 & $1,73 \mathrm{p}$ \\
Coconut Water & 1,34 & 1,56 & 1,69 & $1,53 \mathrm{p}$ \\
\hline Average & $1,61 \mathrm{a}$ & $1,64 \mathrm{a}$ & $1,65 \mathrm{a}$ & $1,63(\mathrm{x})(-)$ \\
\hline Control & & & & $1,57(\mathrm{x})$ \\
\hline \hline
\end{tabular}

Note: The average treatment followed by the same letter in the same row or column shows no significant difference in the Duncan's Multiple Range Test (DMRT) with a 5\% real level. The sign ( $\mathrm{x}$ ) shows no significant difference between the control and the treatment in the Orthogonal Contras test. The (-) sign indicates there is no interaction.

The analysis of the mean dry weights per sample plot showed that the control treatment group with a combination of treatments had no significant effect. Likewise, the treatment of natural growth regulating substances and the administration of bovine biourine concentration had no significant effect on the weight of dried tubers per sample plot. There were no interactions between the two treatments. The average dry tuber weights per sample plot of 60 days are presented in Table 4. Dried tuber weights per plot of control treatment samples with a combination treatment of natural growth regulators plus cow biourine were not significantly different. The control applicating Urea and Za supplement fertilizer can be replaced by application of cow biourine. This is in line with the parameters of the number of tubers produced per clump. Nitrogen and Phosphorus nutrients in cow biourine can speed up the plant growth and enable optimal rate of photosynthesis that increases carbohydrate content. The photosynthate results will be stored in the tubers as food or biomass reserves, making the result that is no different from the control group.

Likewise, the application of cow biourine concentrations of $30 \%, 40 \%$, and $50 \%$ did not show any significant difference in the weight of dried tubers per sample plot. This indicates optimal nutrient absorption and the same in the range of the three concentrations of the biourine, so that the dry tuber weight per plot of sample as a result of photosynthate is also optimal and not significantly different. Treatment with natural growth regulators of sprouts extract, banana stem extract, and coconut water did not show any significant difference in the dry tuber weights per sample plot. This is in accordance with the parameter number of tubers per clump. The hormones contained in these three natural growth regulators are auxin, cytokinin and gibberellin, all of which play a significant role in the process of tuber germination and early growth.

\section{CONCLUSION}

Based on this study, we can draw the following conclusions:

1. The combination of the treatment of natural regulatory substances with the supplementation of cow biourine shows the same results as the control group using chemical fertilizer on the growth and yield of shallot.

2. There is no correlation between the treatment of natural growth regulators and the application of cow biourine concentrations to all growth parameters and yields of shallot.

3. Treatment of natural growth regulators of banana stem extract, coconut water and sprout extract indicates equally good result on the growth and yield of shallot.

4. The application of cow biourine concentration shows the same results on the growth and yield of shallot.

\section{ACKNOWLEDGEMENTS}

The authors would like to exert gratitude to Kemenristek Dikti for the financial assistance provided through an internal applied research grant as well as to the LPPM of UPN "Veteran" Yogyakarta for all the facilities that help the implementation of this research.

\section{REFERENCES}

Arumingtiyas, W. I. 2014. Pengaruh Aplikasi "Biourin" Terhadap Pertumbuhan dan Hasil Tanaman Padi. Jurnal Produksi Tanaman. Vol 2 No 8. 
BPS and Direktorat Jenderal Hortikultura. 2017. Statistik Pertanian. Jakarta Selatan: Pusat Data dan Sistem Informasi Pertanian Kementrian Pertanian Republik Indonesia.

Elisabeth, D.W., M. Santoso, and N. Herlina. 2013. Pengaruh Pemberian Berbagai Komposisi Bahan Organik pada Pertumbuhan dan Hasil Tanaman Bawang Merah (Allium ascalonicum L.). Jurnal Produksi Tanaman, 1(3): 21-29.

Kurniadinata, O.F. 2007. Pemanfaatan Feses Urin Sapi Sebagai Pupuk Organik Dalam Perkebunan Kelapa Sawit. Seminar Optimasi Hasil Perkebuan Kelapa Sawit dan Industri Olahannya Sebagai Pakan Ternak. Paser, Kalimantan Timur. July 2007: 65-72.

Leopold, A. C. 1963. Auxin and Plant Growth. Univ. California Press. Berkeley. Los Angeles

Marfiani, M., Y.S. Rahayu, and E. Ratnasari. 2014. Pengaruh Pemberian Berbagai Konsentrasi Filtrate Umbi Bawang Merah Rootone F Terhadap Pertumbuhan Stek Melati "Rato Ebu". Jurnal Lentera Bio. 3(1): 73-76.
Rizki, K., A. Rasyad, Murniati. 2014. Pengaruh Pemberian Urin Sapi Yang Difermentasi Terhadap Pertumbuhan dan Produksi Tanaman Sawi Putih (Brassica rafa). Jurnal Online Mahasiswa Fakultas Pertanian. Vol. 1 No 2.

Subhan, N.N. 2004. Pengaruh Pupuk NP Cair dan NPK 15 -15 -15 untuk Meningkatkan Hasil dan Kualitas Buah Tomat Varietas Oval. Journal Hortikultura. 14(4) :253 - 257.

Sutari N.W.S. 2010. Pengujian Kualitas Bio-urine. Tesis Program Studi Bioteknologi Pertanian. Program Pasca Sarjana Fakultas Pertanain. Universitas Udayana, Denpasar.

Waluyo, N and R. Sinaga. 2015. Bawang Merah. Balai Penelitian Sayuran. Yogyakarta.

Weaver, J. 1972. Plant Growth Substances in Agriculture. WH Freeman and Company. San Fancisco. 594 p.

Nurhayati AD. 2006. Domination and Composition Structure Change at Hemic Peat Natural Regeneration Following Burning; A Case Study in Pelalawan, Riau Province. Biodiversitas 7: 154-158. 
THIS PAGE INTENTIONALLY LEFT BLANK 